O. Shaposhnikova ${ }^{1}$, V. Kirvas ${ }^{2}$

${ }^{1}$ Kharkiv National Automobile and Road University, Kharkiv

${ }^{2}$ Ivan Kozhedub Kharkiv National Air Force University, Kharkiv

\title{
APPLICATION OF THE AGILE METHODOLOGY IN THE PRACTICE OF PROJECT-BASED LEARNING IN THE TRAINING OF IT SPECIALISTS
}

Theoretical and practical issues of the active learning methods application using the high-profile methodologies aimed at finding effective learning technologies have been considered. There have been analysed the educational methodologies based on the Agile methodology to solve educational problems, taking into account the values and principles of the Agile methodology formulated in the Agile Manifesto. The project-based learning practice introduction in the educational process with the adaptation of the Agile methodology for teaching the "Architecture and analysis of software requirements", "Software quality and testing", "IT projects management" disciplines has been suggested, and the results of this approach have been analyzed.

Keywords: flexible project management in education, Agile methodology, Agile methodology in education, design technologies of education, IT specialists, technologies of team software development.

\section{Introduction}

General Problem Statement. The modern world of global challenges: the acceleration of social and technological change, the economy and society digitalization, the VUCA environment emergence characterized by the instability, uncertainty, complexity and ambiguity of the modern world, requires radical changes in the higher education. Universities must see this environment as a challenge, and not a threat. In these circumstances, the adaptation to the prevailing conditions is vital. New conditions require new people.

Therefore, on the one hand, the task of a university is to prepare a popular candidate at the labor market. A modern university should focus on the formation of a graduate with such qualities as the ability to a nonstandard, adaptive thinking, the ability to develop a project, to achieve any goal, to formulate tasks that will be clearly defined and understood by each performer, the ability to quickly process information and the mental perception of the processed information, the ability to virtual cooperation, social intelligence, transdisciplinarity, etc.

On the other hand, the customers of the educational service - students - have also been changed. Mastering new technologies from childhood, they are not ready to spend a lot of time on gaining new knowledge and competences. In addition, they prefer convenient ways to obtain information: at a convenient time using any multimedia device [1].

These factors indicate that traditional educational technologies have become ineffective.

A modern university should create an environment for students that would promote the development of relevant competencies. One the approaches is to develop a technology based on the practice-oriented learning, and many researchers consider the method of projectbased learning as the most appropriate mindset of the practice-oriented, competency-based approach.

Another innovation of the modern education today is the Agile methodology introduction into the educational process.

The challenges facing a university today and the opportunities posed by the development of new collaboration technologies have led to the Agile methodology penetrating the education system, and a number of educational practices based on it are already in place today. The Agile methodology, as a project management technology, allows you to develop project work skills.

Analysis of the Recent Research and Publications. Due to a growing interest in innovative teaching methods, in particular to the ones of student-centered active learning technologies, the implementation of which results in students gaining interdisciplinary knowledge and skills, creating real workable products and systems, and applying the Agile approaches to education, there are more and more publications on this topic. These approaches are widely used in the field of training engineering skills as well as specialists in software development (Software) and processing technologies (IT). In addition, the use of the Agile design methods in the educational process occurs in different directions.

So, many authors raise these issues and explore the effectiveness of the Agile and Scrum approaches directly in organizing the learning process.

Manokin M.A., Ozhegova A.R., Shenkman E.A. authors, in their concept-based work, provide a detailed review and analysis of educational approaches combined using the Agile design methods [1]. A special attention has been paid to the two most studied approaches: Agile teaching-learning methodology (ATLM) and eXtremePedagogy (XP), and some rec- 
ommendations have been made to create methods for the learning process.

A number of authors study the project approach use applying the Agile methodology to solve targeted educational, organizational, organizational and methodological problems related to the educational processes of higher education.

So, the work of Tronin V.G. [2] proves the possibility and feasibility of applying flexible project management methodologies. The efficiency of Scrum application by the graduating department is considered, where the Scrum team is a team of teachers.

Molodchyk N.A., Naguibina N.I. authors, in their work [3], offer a model of practice-oriented learning applying the Agile principles in the management of structural units of a university to increase the efficiency and competitiveness of higher education.

The author of the article [4] Nikonova Ye.Z. considers the Scrum features regarding the possibility of applying this methodology in higher education to train specialists in the development and implementation of software products.

Lukashenko M.A. and Tielieguina T.V. authors [5-6] conducted a study of the activities of domestic experts on the implementation of the Scrum method in the learning process and analyzed its results. From the authors point of view, the Scrum-method introduction in the educational process is complicated by the lack of relevant educational and methodological support. Therefore, the possibilities of Scrum as a method of managing the creation of educational products are considered. The attention is paid to the combination of a flexible control based on the Scrum and the classic "cascade" model based on the Gantt chart.

The authors also propose concepts for teaching bachelors and masters, which allow to gain sufficient experience and knowledge for successful work in the IT industry using the Agile methodology [7-8].

Some works [9-11] are devoted to the issues of project-based learning where the practice of talent management on the Scrum technology and the implementation of project-based learning in the format of an IT startup are considered. Students, when developing projects, can embody and realize in their ideas the potential that is very necessary for an innovative and technological development of Ukrainian enterprises. According to the authors [10-11], a startup can become an innovative tool for training future IT professionals, which will help students gain their first practical experience and develop the competencies needed for their future professional activities.

In the context of the practice of applying the project-based learning using the Agile methodology, the formation of a development team plays an important role. The authors analyze the typical problems faced by the management in forming a project team, the typical roles of team members, determine the main and optional roles of team members [12-13] and analyze the experience of forming student project teams, of creating conditions for the "soft skills" formation in demand under present-day conditions [14].

Aim of the Research. Given the challenges of today, and perceiving them as an impetus to find new opportunities in higher education in the training of IT professionals, the scientific community is exploring different approaches to training a specialist in demand in the labor market. The aim of this work is based on the analysis of educational approaches to the formation of the graduate's abilities that will allow him to quickly and thoroughly, easily and firmly master life activities; it is to offer the project-based learning approach with the Agile methodology adaptation, where students learn about the IT industry activities, gain practical experience, learn to manage IT projects.

\section{Statement of basic materials
Prerequisites for the project-based learning implementation

New conditions mean new opportunities. They just need to be used, especially if the previous features are no longer available. Thus, opportunities lie in responding to challenges by changing the philosophy of learning.

Obviously, there are two sides to the learning process: a teacher and a student. The role of a teacher is to start from the role of a teacher who imparts ready-made knowledge, to become a qualified consultant who directs the learning process to solve practical problems, and through management consulting methods, to encourage students to make the right choice of a problem and to identify the ways to solve it. In this mindset, a student becomes an active participant in the learning process; he becomes a teacher's ally in solving problems.

The traditional approach to learning is a process aimed at the acquisition by a student of certain knowledge, skills and abilities. That is, a student must Know, be Able, Possess (a skill). Is it appropriate in nowadays conditions? Obviously, it is not. First, a long transition from Knowledge to Skills leads to the fact that no one needs them anymore. This is especially noticeable when training an IT specialist. Secondly, the process is time consuming: a person carries out many activities, and each type of activities requires its knowledge, skills and abilities [15].

It is therefore necessary to teach abilities. Abilities are the characteristics of an individual that arise from birth or develop over a lifetime based on the experience and practice. An ability is manifested in how quickly and thoroughly, easily and firmly an individual learns the activities.

Knowledge is acquired because a person has the ability to perceive, remember and connect new knowledge with the existing bundle of knowledge. Skills appear only when there is the ability to adapt the acquired 
knowledge to practical activities. A habit appears in the presence of the ability to reproduce the skills to implement knowledge in different situations.

Sustainable human abilities underlie individual conditions and performance. Such innate abilities as imagination, empathy, curiosity, persistence, creativity, etc. can be cultivated and amplified in a right environment. And in an environment where activities do not encourage these abilities, they may be underdeveloped and inactive.

Abilities such as adaptive and critical thinking, emotional and social intelligence, teamwork and meaning-making can be formed and improved over time [15].

Based on this, it is obvious that abilities not only have the key to a long-term and permanent relevance, but they can be cultivated without large investments, taking into account that everybody has them, and in the case of their use, they are rapidly evolving and strengthening.

So, what should a modern graduate of a higher educational establishment with an IT specialty look like?

He must have professional training, which includes a basic academic core, a specialized professional training, project management highly specialized Hard skills, operating in a stable environment and within one profession. He must have Digital skills. This category arose in connection with the global digitalization of our world. And Soft skills. They are universal and help to achieve success in any profession, they provide with high communication skills and self-organization, longterm planning skills, teamwork. Scientists from Harvard and Stanford claim that $85 \%$ of success in professional life depends on Soft skills.

It was believed for a long time that Hard skills should dominate; and therefore, the whole system of the world higher professional education was focused on the formation of Hard skills. But the consciousness of the importance of first soft and then digital competencies over the past 20 years has changed the Western education system. As for domestic higher educational establishments, most of them leave the focus on the formation of basic (hard) competencies in graduates, despite the fact that the lion's share of professional achievements is provided by soft competencies.

A lack of IT specialists with developed relevant skills encourages the IT business to look for ways to solve the problem: they open their own universities, training centers, etc., where they prefer to teach such technologies and training methods as the method of business games, the case method, the project-based learning method, the gamification, the online platforms.

On the other hand, an IT student knows the requirements of a potential employer, assesses the chances of obtaining the necessary competencies in the higher educational establishment where he is studying, decides on the place of further acquisition of the necessary competencies.

\section{Practice of implementing the project-based learning using the Agile methodology}

Taking into account the starting positions of today, higher educational establishments, to solve these challenges of today, are experimenting with different teaching methods and technologies, starting with the inclusion in the educational process of communicative trainings and ending with a complete restructuring of the educational process where the project-based learning dominates.

In the context of the project-based learning implementation, a motivating environment for cognition and development is created, in which the student learns to learn, which motivates him to act in the mindset: to research - to know - to act - to be able through research, projects, communication, collaborations.

When introducing the practice of project-based learning, it is advisable to use an interdisciplinary approach, which aims to form students' interdisciplinary thinking: a student learns to synthesize knowledge of different disciplines, to analyze this knowledge and to apply it to comprehensively understand a problem and to find solutions to it.

The search for new ways of learning encourages the use of effective methods and practices from other areas. So, it is natural to turn to the Agile philosophy, which has proven itself in the best way in software development and in the training of IT professionals. The philosophy of flexible work allows higher educational establishments to quickly adapt to changes and requirements of employers, and the Agile technology, as the one of project management, allows students to develop skills for project work.

The Agile methodology use in the practice of project-based learning is due to the fact that the Agile methodology is a much broader concept than methods and practices; it is a way of behavior, a culture and a way of thinking. It is not just a methodology, it is a common name of different methods and approaches to learning management, which focus team members on working together, teach to develop a strategy and tactics, to work in short cycles, they actively use feedback, they determine the choice by each participant of his area of responsibility, they have basically a personalityoriented approach. Therefore, the educational approach - a project-based learning is based on values borrowed from the Agile Manifesto.

The practice of implementing a project-based learning using the Agile methodology was applied in order to:

- help students get acquainted with different areas of IT, learn to work in a team, as well as understand their preferences for the type of activities;

- students receive an assessment of their activities;

- help the student to deliberately choose a master's specialty direction, or to make sure that his available 
knowledge is enough for a successful work in the field.

The practical implementation of a project-based learning with the Agile methodology adaptation at the Computer Technology and Mechatronics Academic Department (CTM) as an experiment is as follows. The "Architecture and analysis of software requirements", "Software quality and testing", "IT projects management" disciplines, which are taught by the work's author, from the second year to the fourth, are combined into a kind of educational module. Within this module of disciplines, students must go through the main stages of the software development life cycle: a project concept development, the requirements writing, the architecture planning, the code development, the testing. To create a holistic picture of the educational process and to qualitatively implement certain stages of the project, because, for example, the code development requires competencies that are formed within the other disciplines, this module is integrated with the other disciplines.

In contrast to a traditional educational process, where the unit of time is a semester, and students and teachers receive learning outcomes every 4 months, the Agile sprints introduction reduces the feedback cycle, allows to respond quickly to any changes.

Therefore, in practice, a semester is divided into sprints, and the duration of a sprint is 1 week (according to the schedule). Each sprint begins with a planning meeting, where students think about future work and assess the efforts that will be needed during the next week. The sprint ends with a retrospective (additional lesson-consultation): students analyze the work done, identify achievements and areas for improvement. Short feedback cycles also allow teachers to quickly identify problems and to take appropriate action.

Different approaches have been used to form teams, and the Agile methodology involves teamwork and collaboration, putting people and their interactions above processes and tools. The most interesting result was obtained when the motivating factor for the formation of a team was the project idea.

At the first stage, the students of an academic group are invited to choose a project topic without restrictions: any idea has a right to exist. As the experience has shown, at this stage, a team of like-minded people is being formed. The student leaders (first group) are immediately involved in the process; they are actively generating immediately discussed ideas. The students who fail to go beyond the specific tasks (second group) need time to adapt to a format unusual for them. In the process of discussing the ideas of the student leaders, some students from the second group begin to join the process of discussing the suggested ideas, which eventually leads to the formation of project teams. Then, the formation of project teams continues with the students of the second group who were not included in the already formed teams, by offering them to carry out projects in a particular area, and if necessary, by formulating a specific project theme, i.e. by creating the conditions familiar for such students. Thus, all the students of the academic group receive assignments and start working on projects.

In each project team before starting work, the roles are agreed, which in the process of work can be changed if necessary; the project teams can also change their composition. This develops the ability to adapt, which helps to maintain team spirit at the level of the whole group, not just at the team level.

One of the Agile methodology key principles is to build projects with motivated people. Students are motivated by success, by recognition of work results, by a high degree of responsibility, by the ability to realize their creative potential. If something went wrong, then according to the Agile methodology, the leader's task is to explain what mistake the performers made, and not to punish.

Motivators for students were at least a certification in subject module disciplines, and at most, a participation in competitions and contests of students of different levels, a bachelor's thesis defense, a creation of a meaningful portfolio in contrast to the traditional educational process, where a success is motivated by marks. In addition, students enjoy working on a real project, the topic of which is interesting for all the team members.

It should be noted about the "IT projects management" discipline taught last in the educational module. Given that students have gained practical experience working in a team, and some of them have tried themselves in the role of a Scrum master, the task of teaching the discipline for this category of students is to structure the already gained knowledge, and it is focused on finding and applying the latest advances in this field. In the future, it is planned to involve fourth-year students, within the "IT projects management" discipline, in the role of project managers of the junior project teams.

\section{Results of the project-based learning implementation using the Agile methodology}

Thus, the introduction of the practice of projectbased learning with the adaptation of the Agile methodology has achieved its goal.

This practice clearly helps students get acquainted with different areas of IT and determine the priority of their future activities. The result of teamwork is very important. The application of the described approach made it possible to form the motivated project groups, where the ability to analyze and to think critically was acquired, nonstandard solutions and innovative ideas were generated, where the students learned to interact, to create an atmosphere of cooperation, where everyone worked for results.

In addition, the interdisciplinary approach application plays an important role when students have a conscious demand for knowledge to develop and acquire professional competencies. The ability to constantly 
learn is the ability of both the present and the future.

The students received their work evaluation in various formats. Most often, the completed projects ended with the defense of complex bachelor's theses with the development up to the master's theses, with a participation in scientific conferences of various levels, with a publication of the outcomes of their achievements in professional publications [17-18] and with a victory in an all-Ukrainian competition of student works.

The CTM Academic Department Graduates, who studied applying the project-based learning using the Agile methodology, are employed in various positions of IT companies.

But, even with the positive result of this approach implementation, there are a number of problems related to the management of its practical implementation on a larger scale involving the other teachers of the institution. These problems require a detailed analysis and they are the subject of a further research.

\section{Conclusions}

As a result, the theoretical and practical issues of the application of active learning methods using the highprofile methodologies aimed at finding effective learning technologies were considered. An analysis of the educational methodologies based on the Agile methodology to solve educational problems, taking into account the values and principles of the Agile methodology formulated in the Agile Manifesto, was carried out. The projectbased learning practice introduction in the educational process with the Agile methodology adaptation for teaching the "Architecture and analysis of software requirements", "Software quality and testing", "IT projects management" disciplines has been suggested, and the results of this approach have been analyzed.

The obtained results have been analyzed and the conclusions have been made, where both the positive experience of implementing this approach and the problems that need a further research have been identified.

\section{References}

1. Manokin, M.A., Ozegova, A.R. and Shenkman, E.A. (2018), "Metodologiya Agile v obrazovatel'noj srede" [Agile methodology in the educational environment], University management: practice and analysis, No. 4(116), pp. 83-96, available at: https://cyberleninka.ru/article/n/metodologiya-agile-v-obrazovatelnoy-srede (accessed 10 August 2020).

2. Tronin, V.G. (2016), "Vozmozhnosti primeneniya gibkih metodologij upravleniya proektami pri obuchenii v vuze po tekhnicheskim special'nostyam" [Possibilities of using flexible project management methodologies when studying at a university in technical specialties], Bulletin of Ulyanovsk State Technical University, No. 3(75), pp. 4-6, available at: $\mathrm{https://cyberleninka.ru/article/n/vozmozhnosti-primeneniya-gibkih-metodologiy-upravleniya-proektami-pri-obuchenii-v-vuze-po-}$ tehnicheskim-spetsialnostyam (accessed 10 August 2020).

3. Molodchik, N.A and Nagibina, N.I. (2019), "Formirovanie i vnedrenie modeli praktiko-orientirovannogo obucheniya v universitete na osnove agile-principov" [Formation and implementation of a model of practice-oriented teaching at the university based on agile principles], Bulletin of the Perm National Research Polytechnic University, No. 1, pp. 44-53, available at: $\mathrm{https}$ //cyberleninka.ru/article/n/formirovanie-i-vnedrenie-modeli-praktiko-orientirovannogo-obucheniya-v-universitete-naosnove-agile-printsipov (accessed 10 August 2020).

4. Nikonova, E.Z. (2018), "Metodologii upravleniya programmnymi proektami v podgotovke IT-specialistov" [Methodologies for managing software projects in the training of IT specialists], Russian Journal of Education and Psychology, No. 2(2), pp. 167-173, available at: https://cyberleninka.ru/article/n/metodologii-upravleniya-programmnymi-proektami-v-podgotovke-itspetsialistov (accessed 10 August 2020).

5. Lukashenko, M.A. and Telegina, T.V. (2019), "Upravlenie sozdaniem obrazovatel'nyh produktov s pomoshch'yu metoda Scrum" [Management of the creation of educational products using the Scrum method], Research Azimuth: Economics and Management, No. 2(27), pp. 223-226, available at: https://cyberleninka.ru/article/n/upravlenie-sozdaniem-obrazovatelnyh-produktovs-pomoschyu-metoda-scrum (accessed 10 August 2020).

6. Lukashenko, M.A. and Telegina, T.V. (2019), 'Nauchit' studenta dumat': Scrum kak metod produktivnogo obucheniya v uchebnom zavedenii" [Teach the student to think: Scrum as a method of productive learning in an educational institution], Azimuth of scientific research: pedagogy and psychology, No. 2(27), pp. 138-142, available at: https://cyberleninka.ru/article/n/nauchitstudenta-dumat-scrum-kak-metod-produktivnogo-obucheniya-v-uchebnom-zavedenii (accessed 10 August 2020).

7. Dolgova, T.G. and Filatova, K.V. (2014), "Ispol'zovanie novyh obrazovatel'nyh tekhnologij pri podgotovke ITspecialistov" [The use of new educational technologies in the training of IT specialists], Reshetnevskie readings, No. 18, pp. 7578, available at: https://cyberleninka.ru/article/n/ispolzovanie-novyh-obrazovatelnyh-tehnologiy-pri-podgotovke-it-spetsialistov (accessed 10 August 2020).

8. Kudinova, O.S. and Skulmovskay, L.G. (2018), "Proektnaya deyatel'nost' v vuze kak osnova innovacij” [Project activity at the university as the basis of innovation], Modern problems of science and education, No. 4, available at: www.scienceeducation.ru/ru/article/view?id=27928 (accessed 10 August 2020).

9. Volkova, N.V. and Plotnikov, V.A. (2017), "Praktika upravleniya talantami: proektnaya rabota po tekhnologii scrum" [Talent management practice: project work on scrum technology], University Management: Practice and Analysis, No. 21(2), pp. 131-143. https://doi.org/10.15826/umpa.2017.02.027.

10. Plokhaya, E.B. (2015), "Mekhanizm proektnogo obucheniya v formate IT-startapa" [The mechanism of project-based learning in the format of an IT startup], Information Processing Systems, No. 4(129), pp. 171-173.

11. Polushkina, A.O. "Tekhnologiya ispol'zovaniya startapa v processe obucheniya stude" [Technology of using a startup in the process of teaching students], Bulletin of the Belarusian State University, No. 7, pp. 166-175, available at: https:/cyberleninka.ru/ article/n/tehnologiya-ispolzovaniya-startapa-v-protsesse-obucheniya-studentov (accessed 10 August 2020).

12. Bocharova, O.O. and Mnushka, O.V. (2020), "Rol' maloï grupi v komandi fahivciv pri roboti nad programnim proektom" [The role of a small group in a team of specialists in a software project], Proceedings of the II International scientific- 
practical conference "Computer Technology and Mechatronics", Kharkiv, Ukraine, pp. 22-25.

13. Mnushka, O.V. and Savchenko, V.M. (2020), "Formuvannya ta keruvannya komandoyu rozrobnikiv programnogo zabezpechennya" [Formation and management of a team of software developers], Bulletin of the National Technical University “Kharkiv Polytechnic Institute”, No. (3), pp. 99-112. https://doi.org/10.20998/2411-0558.2020.01.09.

14. Yarkova, T.A. and Cherkasova, I.I. (2016), "Formirovanie gibkih navykov u studentov v usloviyah realizacii professional'nogo standarta pedagoga" [Formation of flexible skills among students in the context of the implementation of the professional standard of a teacher], Bulletin of Tyumen State University, No. 4(2), pp. 222-234.

15. Hagel, J., Brown, J.S. and Wooll, M. (2019), Skills change, but capabilities endure. Why fostering human capabilities first might be more important than reskilling in the future of work, available at: https://www2.deloitte.com/us/en/insights/ focus/technology-and-the-future-of-work/future-of-work-human-capabilities.html (accessed 10 August 2020).

16. Meshcheryakova, M.A., Shalnev, O.G. and Filatova, M.V. (2020), "Strategii razvitiya universal'nyh navykov dlya VUCA-mira" [Strategies for Developing Universal Skills for the VUCA World], Voronezh State University of Engineering Technologies Bulletin, No. 82(3), pp. 279-283. https://doi.org/10.20914/2310-1202-2020-3-279-283.

17. Lantrat, O.V., Sakhno, Y.V. and Shaposhnikova, O.P. (2019), "Rozroblennya mobil'nogo dodatku "Mis'ki parkovki”"“ [Development of a mobile application "City Parking"], Bulletin of Kharkiv National Automobile and Road University, No. 87, pp. 59-66.

18. Lantrat, O.V., Sakhno, Y.V. and Shaposhnikova, O.P. (2020), "Arhitektura dodatku dlya poshuku misc' dlya pakuvannya" [Architecture of the application for finding parking spaces], Bulletin of Kharkiv National Automobile and Road University, No. 89, pp. 7-15.

\section{Список літератури}

1. Манокин М.А. Методология Agile в образовательной среде [Электронный ресурс] / М.А. Манокин, А.Р. Ожегова, Е.А. Шенкман // Университетское управление: практика и анализ. - 2018. - № 4(116). - С. 83-96. - Режим доступа: https://cyberleninka.ru/article/n/metodologiya-agile-v-obrazovatelnoy-srede.

2. Тронин В.Г. Возможности применения гибких методологий управления проектами при обучении в вузе по техническим специальностям [Электронный ресрурс] / В.Г. Тронин // Вестник Ульяновского государственного технического университета. - 2016. - № 3(75). - С. 4-6. - Режим доступа: https://cyberleninka.ru/article/n/vozmozhnosti-primeneniyagibkih-metodologiy-upravleniya-proektami-pri-obuchenii-v-vuze-po-tehnicheskim-spetsialnostyam.

3. Молодчик Н.А. Формирование и внедрение модели практико-ориентированного обучения в университете на основе agile-принципов [Электронный ресрурс] / Н.А. Молодчик, Н.И. Нагибина // Вестник Пермского национального исследовательского политехнического университета. - 2019. - № 1. - С. 44-53. - Режим доступа: https://cyberleninka.ru/article/n/formirovanie-i-vnedrenie-modeli-praktiko-orientirovannogo-obucheniya-v-universitete-naosnove-agile-printsipov.

4. Никонова Е.3. Методологии управления программными проектами в подготовке IT-специалистов [Электронный pecypc] / Е.3. Никонова // Russian Journal of Education and Psychology. - 2018. - № 2(2). - С. 167-173. - Режим доступа: https://cyberleninka.ru/article/n/metodologii-upravleniya-programmnymi-proektami-v-podgotovke-it-spetsialistov.

5. Лукашенко М.А. Управление созданием образовательных продуктов с помощью метода Scrum [Электронный ресурс] / М.А. Лукашенко, Т.В. Телегина // Азимут научных исследований: экономика и управление. - 2019. - № 2(27). - С. 223-226. Режим доступа: https://cyberleninka.ru/article/n/upravlenie-sozdaniem-obrazovatelnyh-produktov-s-pomoschyu-metoda-scrum.

6. Лукашенко M.A. Научить студента думать: Scrum как метод продуктивного обучения в учебном заведении [Электронный ресурс] / М.А. Лукашенко, Т.В. Телегина // Азимут научных исследований: педагогика и психология. 2019. - № 2(27). - С. 138-142. - Режим доступу: https://cyberleninka.ru/article/n/nauchit-studenta-dumat-scrum-kak-metodproduktivnogo-obucheniya-v-uchebnom-zavedenii.

7. Долгова Т.Г. Использование новых образовательных технологий при подготовке ИТ-специалистов [Электронный ресурс] / Т.Г. Долгова, К.В. Филатова // Решетневские чтения. - 2014. - № 18. - С. 75-78. - Режим доступа: https://cyberleninka.ru/article/n/ispolzovanie-novyh-obrazovatelnyh-tehnologiy-pri-podgotovke-it-spetsialistov.

8. Кудинова О.С. Проектная деятельность в вузе как основа инноваций [Электронный ресурс] / О.С. Кудинова, Л.Г. Скульмовская // Современные проблемы науки и образования. - 2018. - № 4. - Режим доступа: http://www.scienceeducation.ru/ru/article/view?id=27928.

9. Волкова Н.В. Практика управления талантами: проектная работа по технологии scrum / Н.В. Волкова, В.А. Плотников // Университетское управление: практика и анализ. - 2017. - № 21(2). - С. 131-143. https://doi.org/10.15826/umpa.2017.02.027.

10. Плохая Е.Б. Механизм проектного обучения в формате ІТ-стартапа / Е.Б. Плохая // Системи обробки інформації. - 2015. - № 4(129). - С. 171-173.

11. Полушкина А.О. Технология использования стартапа в процессе обучения студентов [Электронный ресурс] / А.О. Полушкина // Вестник Белорусского государственного университета. - 2017. - № 7. - С. 166-175. - Режим доступа: https://cyberleninka.ru/article/n/tehnologiya-ispolzovaniya-startapa-v-protsesse-obucheniya-studentov.

12. Бочарова О.О. Роль малої групи в команді фахівців при роботі над програмним проектом / О.О. Бочарова, О.В. Мнушка // Збірник наукових праць за матеріалами II міжнародної науково-практичної конференції “Комп'ютерні технології і мехатроніка". - Харків, 28 травня 2020 р. - С. 22-25.

13. Мнушка О.В. Формування та керування командою розробників програмного забезпечення / О.В. Мнушка, В.М. Савченко // Вісник Національно-технічного університету “Харківський політехнічний інститут”. - 2020. - № 1(3). C. 99-112. https://doi.org/10.20998/2411-0558.2020.01.09.

14. Яркова Т.А. Формирование гибких навыков у студентов в условиях реализации профессионального стандарта педагога / Т.А. Яркова, И.И. Черкасова // Вестник Тюменского государственного университета. - 2016. - № 4(2). - С. $222-234$.

15. Hagel J. Skills change, but capabilities endure. Why fostering human capabilities first might be more important than reskilling in the future of work [Electronic resource] / J. Hagel, J.S. Brown, M. Wooll. - 2019. - Available at: https://www2.deloitte.com/us/en/insights/focus/technology-and-the-future-of-work/future-of-work-human-capabilities.htm. 
16. Мещерякова М.A. Стратегии развития универсальных навыков для VUCA-мира / М.A. Мещерякова, О.Г. Шальнев, М.В. Филатова // Вестник Воронежского государственного университета инженерных технологий. 2020. - № 82(3). - C. 279-283. https://doi.org/10.20914/2310-1202-2020-3-279-283.

17. Лантрат О.В. Розроблення мобільного додатку "Міські парковки” / О.В. Лантрат, С.В. Сахно, О.П. Шапошнікова // Вісник Харківського національного автомобільно-дорожнього університету. - 2019. - № 87. - С. 59-66.

18. Лантрат О.В. Архітектура додатку для пошуку місць для паркування / О.В. Лантрат, Є.В. Сахно, О.П. Шапошнікова // Вісник Харківського національного автомобільно-дорожнього університету. - 2020. - № 89. - С. 7-15.

Received by Editorial Board 11.08.2020

Signed for Printing 15.09.2020

Відомості про авторів:

Шапошнікова Олена Павлівна кандидат технічних наук доцент доцент кафедри

Харківського національного

автомобільно-дорожнього університету, Харків, Україна

https://orcid.org/0000-0002-0405-8205

Кірвас Валерія Вікторівна

науковий співробітник

Харківського національного університету

Повітряних Сил ім. І. Кожедуба,

Харків, Україна

https://orcid.org/0000-0001-5310-6587

\section{Information about the authors:}

Olena Shaposhnikova

Candidate of Technical Sciences Associate Professor

Senior Lecturer

of Kharkiv National Automobile

and Road University,

Kharkiv, Ukraine

https://orcid.org/0000-0002-0405-8205

Valeriya Kirvas

Research Associate

of Ivan Kozhedub Kharkiv National

Air Force University,

Kharkiv, Ukraine

https://orcid.org/0000-0001-5310-6587

\title{
ЗАСТОСУВАННЯ МЕТОДОЛОГIÏ AGILE В ПРАКТИЦІ ПРОЕКТНОГО НАВЧАННЯ ПРИ ПІДГОТОВЦІ ІТ СПЕЦІАЛІСТІВ
}

\author{
О.П. Шапошнікова, В.В. Кірвас
}

Сучасні виклики глобального світу - прискорення сочіальних та технологічних змін, ичифровізації економіки та суспільства, виникнення середовища VUCA, яке характеризує нестабільність, невизначеність, складність і неоднозначність сучасного світу вносять суттєві корективи в ринок прачі: нові умови вимагають нових людей. Враховуючи виклики сучасності, та сприймаючи їх, як поштовх до пошуку нових можливостей у системі вищої освіти при підготовиі IT спеціалістів, наукове співтовариство досліджує різні підходи для підготовки затребуваного ринком праці спеціаліста. Як показав аналіз публікацій, перспективною є концепція, де у иентрі системи освіти стоїть студент, його запит на розвиток, враховуються його особливості і можливості, нахили, здібності і устремління, де створюється освітне середовище, в якому студент стає активним учасником процесу навчання, стає союзником викладача у вирішенні проблем. Метою даної роботи є на основі аналізу освітніх підходів для формування у випускника здатностей, які дозволять йому швидко і трунтовано, легко і міцно освоювати види діяльності протягом життя, запропонувати впровадження проектного навчання з адаптацією Agile з урахуванням цінностей і принципів Agile методології, сформульованих у маніфесті. Практична реалізація цього підходу передбачає створення освітнього модуля дисииплін: “Архітектура та аналіз вимог до ПЗ”, “Якість ПЗ та тестування”, “Управління ІТ проектами”, в рамках якого студенти мають пройти основні етапи життєвого цииклу розробки програмного забезпечення: розроблення концепиії проекту, написання вимог, планування архітектури, розробка коду, тестування, отримати досвід управління проектами, а для створення цілісної картини освітнього процесу та для якісного виконання окремих етапів проекту, ией модуль інтегрується з іншими навчальними дисииплінами. Впровадження проектного навчання з використанням Agile методології було застосоване 3 метою: допомогти студентам ознайомитися з різними галузями IT, навчитися роботі в команді, а також зрозуміти свої вподобання щцодо виду діяльності; отримання студентом оцінки своєї діяльності; допомогти студенту виважено вибрати напрямок спеціальності магістра, або впевнитись, щчо наявних у нього знань достатньо для успішної роботи в галузі. Наведені результати впровадження такого підходу свідчить про досягнення поставленої мети, а проблеми з які з'явились в прочесі практичної реалізачії потребують детального аналізу та є предметом подальшого дослідження.

Ключові слова: гнучке управління проектами в освіті, Agile-методологія, Agile в освіті, проектні технології освіти, ІТ-спеціалісти, технології командної розробки програмного забезпечення.

\section{ИСПОЛЬЗОВАНИЕ МЕТОДОЛОГИИ AGILE В ПРАКТИКЕ ПРОЕКТНОГО ОБУЧЕНИЯ ПРИ ПОДГОТОВКЕ ИТ СПЕЦИАЛИСТОВ}

\section{Е.П. Шапошникова, В.В. Кирвас}

Рассмотрены теоретические и практические вопросы применения методов активного обучения с использованием гибких методологий, которые имеют иелью поиск эффективных технологий обучения. Проведен анализ образовательных методологий, основанных на Agile для решения образовательных проблем с учетом иенностей и принципов Agile методологии, сформулированных в манифесте. Предложено внедрение в учебный прочесс практику проектного обучения с адаптаиией Agile методологии для преподавания дисииллин "Архитектура и анализ требований к программному обеспечению”, “Качество программного обеспечения и тестирование”, “Управление ИТ проектами” и проанализированы результаты такого подхода.

Ключевые слова: гибкое управление проектами в образовании, Agile-методологии, Agile в образовании, проектные технологии образования, ИТ-специалисты, технологии командной разработки программного обеспечения. 